\title{
National Wealth and National Intelligence as Determinants of National Productivity and National Innovation
}

\author{
William DiPietro \\ Department of Accounting and Business, Daemen College \\ 4380 Main St., Amherst, NY 14226, USA \\ Tel: 1-716-839-8427Ｅ-mail: wdipietr@daemen.edu
}

Received: May 1, 2015

Accepted: May 21, 2015

Published: June 23, 2015

doi:10.5296/ieb.v2i1.7881

URL: http://dx.doi.org/10.5296/ieb.v2i1.7881

\begin{abstract}
This paper proposes that both national productivity and national innovation depend positively on two key variables, the amount of national wealth and the extent of national intelligence. To test these ideas, the paper employs cross country regression analysis on a large set of countries from around the world. Overall, the regression results of the paper lend support to the idea. Empirically, it appears that national productivity is positively related to national wealth and national intelligence, and that national innovation is positively related to national wealth and national innovation.
\end{abstract}

Keywords: National I.Q., Innovation, Wealth, Productivity, Cross country regression analysis 


\section{Introduction}

All nations are interested in enhancing their productivity and in fostering innovation. Productivity improvement is the fundamental means for generating a higher standard of living for society, and innovation, in its turn, is a key driver of productivity growth. Understanding productivity and innovation is important not just for the present but for the future welfare of a nation. If the causes of greater innovation and productivity can be identified and understood, then more effective policy can be designed and implemented to improve a nation's material well being.

Now, what determines national productivity and national innovation? A simple notion is that country productivity and country innovation depend on just two things. They are, first, what a country has to work with, that is, a country's wealth, and, second, a country's ability to work with, to effectively use, what it has, that is, a country's cognitive ability.

The purpose of this paper is to test to see whether or not national productivity and national innovation depend on national wealth and national intelligence.

The paper is unique in a few respects. First, instead of using a traditional production function as its underlying theoretical basis, it uses an alternative style production function with wealth and intelligence as the key arguments. Second, while most investigations use GDP per capita or economic growth as the country performance variable, here, national productivity and national innovation are employed as alternative country performance variables. Third, whereas a lot of empirical work employs per capita income as one of the key variables to explain economic performance, the present study, in its place, uses national wealth.

The paper is organized into five sections. The first section reviews a bit of the recent literature that touches on the potential consequences of national wealth and national intelligence on essential economic outcomes. The second section provides a theoretical framework formally spelling out the two proposed relationships, the first, between national productivity, national wealth, and national intelligence, and the second, between national innovation, national wealth, and national intelligence. The third section identifies the variables that are used in the empirical analysis and indentifies their sources. The fourth section presents the cross country results of regressions of productivity and innovation on wealth and on intelligence. The fifth and the last section ends the paper with some concluding remarks and with a few policy considerations.

\section{Some Background Literature}

Looking strictly at the natural resource component of total national wealth, in the book, Natural Resources, Neither Curse nor Destiny, consisting of a compendium of articles edited by Lederman and Maloney, the case is made, econometrically, historically, and on a theoretical basis, that natural resource wealth, if it is used wisely, can be a blessing for economic development (Lederman \& Maloney, 2007).

Hibbs and Olsson use an historical-geographical approach to explain current differences in per capita incomes between nations (Hibbs \& Olsson, 2004). They put forth the notion that 
initial geographic and biogeographic endowments ten thousand years ago, such as climate, latitude, and the local numbers of available domesticatable wild plants and animals, explain the historical differences in the timing of the agricultural revolution at different places around the world, and are the major source of present day differences in the standard of living between countries. Their cross country regressions, using a sample of one hundred twelve countries, indicate that initial biogeographic wealth, when adjusting for institutional quality, is responsible for a sizable portion of the present variation in per capita income across countries.

Ram uses a Mankiw, Romer and Weil production function based growth equation specification in which he adds IQ and institutional quality in his cross country regressions to explain economic growth (Ram, 2007). He concludes, from his empirical findings, that IQ is a better proxy for human capital than either education or health.

Weede and Kampf run two sets of cross country regressions of long term GDP per capita growth on average national IQ scores (Weede \& Kampf, 2002). In the first set, they adjust for national investment, human capital, and the level of economic development. In the second, they add the extent of freedom and the amount of improvement in freedom as two additional control variables. In general, they find that IQ really seems to be of import for economic growth with IQ having a larger standardized effect on economic growth than any other variable when IQ enters an equation.

Jones and Schneider employ a Bayesian averaging of classical estimates approach to empirically explore the relationship between national IQ and economic growth (Jones \& Schneider, 2005). They run 1330 regressions of average national growth from 1960 to 19992 on Lynn and Vanhanen's average national IQ scores in combination with other explanatory variables, and find a statistically robust positive relationship between national growth and national IQ.

Jones tries to explain why the macroeconomic differences in income per capita due to intelligence between countries is so much larger than the microeconomic differences in wages between individuals within countries due to intelligence (Jones, 2011). He puts forth several cognitive spillover reasons. One is that greater intelligence is associated with greater time patience leading to higher national savings rates. Another is that greater intelligence is associated with more cooperative behavior improving the functioning of national institutions.

The determinants of innovation at the individual level may have potential implications for its determinants at the national level. Patterson reviews the psychological literature on innovation at the level of the individual by looking at reasons for individual differences in the propensity to innovate between individuals (Patterson, 2002). A few highlights from her article include, first, that innovation is a process and that different mental functions may be needed at different phases (the idea generation phase and the implementation phase), second, that although intelligence is a necessary condition for innovation, it is by no means a sufficient condition for innovation, third, that there appears to be an inverted U-shaped relationship between an individual's subject knowledge and innovation with either too much or too little knowledge dulling innovation, fourth, that intrinsic motivation is extremely 
critical for innovation, and, that extrinsic motivation, while it can possibly be beneficial in providing some positive feedback, for the most part, must do its best just to stay out of the way and not become a hindrance to innovation, and, fifth, that the personality trait of openness, and perhaps, agreeableness, conscientiousness, and psychoticism, are positively related to innovation.

\section{The Productivity, Innovation, Wealth, Intelligence Nexus}

The model is composed of two equations, one with productivity as the dependent variable and the other with innovation as the dependent variable. For each of two equations, the two major arguments on the right hand side of the equations are the same. They are wealth and intellectual ability.

Formally, the two equations are as follows.

$$
\begin{array}{ll}
\text { 1. } \mathrm{P}=\mathrm{f}(\mathrm{W}, \mathrm{I}, \mathrm{C}) & \delta \mathrm{P} / \delta \mathrm{W}>0, \delta \mathrm{P} / \delta \mathrm{I}>0 \\
\text { 2. } \mathrm{V}=\mathrm{h}(\mathrm{W}, \mathrm{I}, \mathrm{C}) & \delta \mathrm{P} / \delta \mathrm{W}>0, \delta \mathrm{P} / \delta \mathrm{I}>0
\end{array}
$$

In the equations, $\mathrm{P}$ represents productivity, $\mathrm{W}$ is national Wealth, $\mathrm{I}$ is national intellectual ability, $\mathrm{V}$ is national innovation, and $\mathrm{C}$, a vector or set of other relevant variables.

In words, the first equation essentially says that national productivity depends directly on national wealth and on national intelligence, so that an increase in national wealth or an increase in national intelligence leads to an increase in national productivity. Similarly, the second equation puts forth the notion that national innovation is positively related to national wealth and national intelligence.

For each of the equations, the essential reasoning is that what men can accomplish in any situation depends on what they have to work with in a given situation (national wealth), and their inherent ability and talent to make good in any situation which they confront (national intelligence).

Regardless of the level of a nation's endowment, higher national IQ is considered to be crucial for economic performance. Higher IQ individuals are hypothesized to be more productive than lower IQ individuals, to adjust faster and better to any situation, to adapt faster and better to any technology (be it old or new), to be more prone to come up with valuable new ideas, and to be more effective in generating solutions to both simple and complex problems.

Besides national wealth and national intelligence, there are other variables that are likely to be relevant (represented by the $\mathrm{C}$ in each of the three equations). Only one control variable is considered in this paper. It is the effectiveness of government policy. Good government policy is expected to be positive for national productivity and innovation while bad policy is expected to be negative.

It should be kept in mind that the classical production function in which output depends on land, labor, and capital is not the only way to specify a production function. Here, output and other economic variables, is considered to depend on a country's wealth endowment and on 
its national intelligence, its ability to work with its national wealth endowment.

\section{Variables and Sources}

National productivity is captured by employing purchasing power parity converted GDP per worker at constant 2005 prices. The numbers come from the Heston, Summers, and Aten's Penn World Data set (Heston, Summers, \& Aten, 2012).

The variable used to gauge national innovation is the 2008 global innovation index of the Confederation of Indian Industry and INSTEAD (Confederation of Indian Industry and Instead, 2010). The Confederation's index ranges from a low value of one to a high value of seven.

National wealth is measured using the World Bank's per capita wealth for 2005 (World Bank, 2011). The world Bank's measure of wealth is extremely comprehensive taking into account both natural capital, produced capital, and intangible capital. For 2005, the World Bank's per capita wealth ranges from a low value of 2191 dollars for Burundi to a high value of 917530 dollars for Luxembourg.

National intelligence, average national intelligence, is proxied by employing the 2006 average IQ index score from Lynn and Vanhanen (Lynn \& Vanhanen, 2006). Lynn and Vanhanen's country IQ scores are normalized with Great Britain equal to 100, and range in value between 59 and 108 .

The lone policy variable, government effectiveness, is the 2009 government effectiveness index of the World Governance Indicators of the World Bank (World Bank, 2013). For 2009, the government effectiveness index has a low value of -1.8 and a high value of 2.2.

\section{The Empirical Results}

Table 1. Cross country regressions of national productivity on national wealth, national intelligence, and national policy effectiveness

\begin{tabular}{|c|c|c|c|c|}
\hline & $(1)$ & $(2)$ & $(3)$ & $(4)$ \\
\hline CONSTANT & 10554.74 & -86491.56 & -27095.48 & -16257.22 \\
& $(8.34)^{*}$ & $(-6.84)^{*}$ & $(-3.52)^{*}$ & $(-1.34)$ \\
\hline \multirow{2}{*}{ WEALTH } & .1063 & & .0901 & .0674 \\
& $(21.97)^{*}$ & & $(17.05)^{*}$ & $(7.57)^{*}$ \\
\hline IQ & & 1336.63 & 469.28 & 379.31 \\
& & $(8.97)^{*}$ & $(4.90)^{*}$ & $(2.66)^{*}$ \\
\hline POLICY & & & & 6735.03 \\
& .769 & .320 & .823 & $(2.91)^{*}$ \\
\hline RSQ & 147 & 173 & 146 & .814 \\
\hline $\mathrm{N}$ & & & & 101 \\
\hline
\end{tabular}


Table 2. Cross country regressions of national innovation on national wealth, national intelligence, and national policy effectiveness

\begin{tabular}{|c|c|c|c|c|}
\hline & $(1)$ & $(2)$ & $(3)$ & $(4)$ \\
\hline CONSTANT & 2.63 & -1.28 & .961 & 1.86 \\
& $(49.74)^{*}$ & $(-2.66)^{*}$ & $(2.58)^{*}$ & $(5.05)^{*}$ \\
\hline \multirow{2}{*}{ WEALTH } & .0000032 & & .0000025 & .0000015 \\
& $(16.93)^{*}$ & & $(11.88)^{*}$ & $(5.57)^{*}$ \\
\hline IQ & & .0505 & .0202 & .0114 \\
& & $(9.23)^{*}$ & $(4.52)^{*}$ & $(2.67)^{*}$ \\
\hline POLICY & & & & .3839 \\
& & & & $(5.29)^{*}$ \\
\hline RSQ & .721 & .409 & .765 & .845 \\
\hline $\mathrm{N}$ & 113 & 125 & 113 & 93 \\
\hline
\end{tabular}

Tables 1 and 2 show respectively the results of cross country regressions of national productivity and national innovation, on wealth, intelligence, and on the single policy control variable, government effectiveness.

Each table contains four equations. The first is the regression of the dependent variable on national IQ alone, the second the regression of the dependent variable on national wealth alone, the third of the dependent variable on wealth and intelligence, and the fourth of the dependent variable on wealth, intelligence, and government effectiveness.

Each table is constructed in a similar fashion. The first column lists the explanatory variables, and, the second, third, fourth, and fifth columns show the results of separate regression runs. The equations are numbered in the first row. Within the body of the table, for any selected variable and selected equation, the top value is the estimated coefficient. Beneath the estimated coefficient in parenthesis is its individual t-statistic. Under the individual t-statistic, a single asterisk appears for a variable that is significant at the one percent level of significance or better in an equation. The last two rows of a table show the $r$ squared values and the sample sizes.

Looking at the two tables, the results are quite impressive. Consistent with the theoretical expectations of the two equation model, the signs of the estimated coefficients of the three explanatory variables, national wealth, national IQ, and government effectiveness are positive in every one of the eight equations in the two tables. This indicates, as theoretically anticipated, that higher levels of national wealth, national IQ, and government effectiveness are associated with greater national productivity and greater national innovation.

Reviewing the individual t-statistics, shows that every one of the three explanatory variables is significant at the one percent level of significant or better any time they appear in an equation. Together, national wealth, National IQ, and the policy variable, government effectiveness explain over eighty two percent of the cross country variation in national productivity, and over seventy six percent of the cross country variation in national 
innovation.

\section{Conclusion}

The empirical analysis of the paper lends support to the hypothesis that national productivity and national innovation are positively related to national wealth and to national intelligence. Whether national wealth or national intelligence are used separately in regressions singularly as lone explanatory variables, together in combination without adjusting for any control variables, or in combination adjusting for a key policy variable, government effectiveness, the regression analysis indicates that both national wealth and national intelligence matter for national productivity and national innovation.

The major policy implication emanating from the results of the paper is that in order to increase innovation and productivity a country needs to enlarge its national wealth and to raise its national intelligence. Although some countries may be favored with natural endowments such as fertile land and oil reserves, and many countries are wealth disadvantaged by not having these natural endowments, many of the important components of national wealth, such as physical capital and institutional quality, are amenable to improvement.

Given the importance of IQ for productivity and innovation, policy must be designed to promote national IQ. National intelligence is, to a large extent, determined by how human beings are treated, especially in the early formative years of their lives. Children need to be well fed and given adequate health care.

Countries must be very careful not to distort incentives for intelligence creation by doing such things as systemically underpaying high IQ workers. Since the market never takes into account externalities, regardless of whether they are positive or negative, higher IQ workers are apt to be underpaid because their wages do not include the positive cognitive spillovers of higher intelligence to society.

Obviously, preventing brain drain should be a real policy concern. Greater brain drain lowers national intelligence leading to lower levels of country productivity and reduced national competitiveness.

The findings with regard to intelligence are of particular relevance with regard to developing countries. If, as the findings of this study show, national intelligence is important for national productivity and for national innovation, then poor developing countries can easily be caught in an unpalatable vicious circle. Because of their poverty, these countries may be unable to provide the majority of their children with sufficient food, nutrition, and health care for maximum brain and intellectual development. The resulting low levels of national intelligence due to the lack of proper care for children assures the future national incomes of these countries will be low, leaving these countries with insufficient future means to rectify the child intelligence formation problem.

In terms of national and international policy, this means that something needs to be done to assure that conditions for proper intellectual development of children in developing countries 
are met. Within developing countries, allocating resources to provide a fruitful environment for proper child development must be given a high priority, and international aid needs be devoted to this cause.

\section{References}

Confederation of Indian Industry and Instead. (2010). Global innovation Index. Retrieved from http://www.globalinnovationindex.org/gii/main/home.cfm

Heston, A., Robert, S., \& Bettina, A. (2012). Penn World Table Version 7.1, Center for International Comparisons of Production. Income and Prices at the University of Pennsylvania. Retrieved from https://pwt.sas.upenn.edu/php_site/pwt71/pwt71_form.php

Hibbs, D. A. Jr., \& Olsson, O. (2004). Geography Biogeography, and Why Some Countries are Rich and Others are Poor. Proceedings of the National Academy of Sciences U.S.A., 101(1), 3715-3720. http://dx.doi.org/10.1073/pnas.0305531101

Jones, G. (2011). IQ and National Productivity, New Palgrave Dictionary of Economics. Retrieved from http://mason.gmu.edu/ gjonesb/IQandNationalProductivity.pdf

Jones, G., \& Schneider, W. J. (2000). Intelligence, Human Capital, and Economic Growth: A Bayesian Averaging of Classical Estimates (BACE) Approach. Journal of Economic Growth, 11(1). 71-93. http://dx.doi.org/10.1007/s10887-006-7407-2

Lederman, D., \& Maloney, W. F. (2007). Natural resources, Neither Curse Nor Destiny. Washington: The International Bank for Reconstruction and Development, World Bank. Retrieved from https://openknowledge.worldbank.org/bitstream/handle/10986/7183/378930LAC0Natu 101OFFICIAL0USE0ONLY1.pdf

Lynn, R., \& Vanhanen, T. (2006). IQ and Global Inequality. Atlanta: Washington Summit Publishers. Retrieved from http://gentlecynic.net/Articles/IQ\%20and\%20Global\%20Inequality.pdf

Patterson, F. (2002). Great Minds Don't Think Alike? Person-Level Predictors of Innovation at Work. International Review of Industrial and Organizational Psychology, 17, 116-144. Retrieved from http://books.google.com/books?hl=en\&lr=\&id=WuiROhPnAtkC\&oi=fnd\&pg=PA115\& $\mathrm{dq}=$ innovation + and $+\mathrm{iq} \&$ ots $=$ Y19fkgtiCo\&sig $=2 \mathrm{gxHqiFFSi0qs} 4 \mathrm{~h} 1 \mathrm{nLiXLvf9aeo \# v=on}$ epage $\& q=$ innovation $\% 20$ and $\% 20$ iq $\& \mathrm{f}=$ false

Ram, R. (2007). IQ and Economic Growth: Further Augmentation of Mankiw-Romer-Weil Model. Economics Letters, 94(1), 7-11. http://dx.doi.org/10.1016/j.econlet.2006.05.005

Weede, E., \& Kampf, S. (2002). The Impact of Intelligence and Institutional Improvements on Economic Growth. Kyklos, 55, 361-380. http://dx.doi.org/10.1111/1467-6435.00191

World Bank. (2011). Changing Wealth of Nations. World Bank, 2011. Retrieved from 
http://siteresources.worldbank.org/ENVIRONMENT/Resources/ChangingWealthNatio ns.pdf

World Bank. (2013). World Wide Governance Indicators. Retrieved from http://databank.worldbank.org/data/views/reports/tableview.aspx

\section{Copyright Disclaimer}

Copyright for this article is retained by the author(s), with first publication rights granted to the journal. This is an open-access article distributed under the terms and conditions of the Creative Commons Attribution license (http://creativecommons.org/licenses/by/3.0/). 